\title{
The Global Spread of Preferential Voting: Australian Institutional Imperialism?
}

\author{
BENJAMIN REILLY \\ Australian National University
}

\begin{abstract}
In recent years, a number of countries have adopted versions of the 'Australian' electoral system of preferential voting for both national and sub-national elections. This article examines the diffusion of preferential voting systems around the world. It distinguishes between various types of preferential voting manifested in both majoritarian (eg alternative vote) and proportional (eg single transferable vote) contexts. It then examines the empirical record of the adoption of preferential voting in Europe, North America and the Pacific, identifying three ways in which the 'Australian' system has been transferred to other countries, via colonial transplanting, international imitation, and normative appeal. While the first two approaches have been traditionally influential, in recent years the normative appeal of preferential voting systems has become paramount. This is in part because of the globalisation of electoral assistance, which has provided an important opportunity for the diffusion of what have been, until recently, distinctively 'Australian' electoral procedures.
\end{abstract}

\section{Introduction}

In recent years, a number of countries in Europe, North America and the Pacific have adopted versions of the 'Australian' electoral system of preferential voting. This article examines these various cases of the diffusion of preferential voting systems around the world. It begins by distinguishing between different forms of preferential voting manifested in both majoritarian (eg alternative vote) and proportional (eg single transferable vote) contexts. It then examines the empirical record of the adoption of preferential voting systems around the world, focussing particularly on the experience of Europe, North America and the South Pacific.

In so doing, the article identifies three distinct forms and sequences of institu-

Benjamin Reilly is a Senior Lecturer in the Asia Pacific School of Economics and Government at the Australian National University. He was previously a Democratic Governance Advisor at the United Nations Development Program in New York and a Senior Program Officer at the International Institute for Democracy and Electoral Assistance in Stockholm. His work focuses on electoral systems, political institutions and ethnic conflict. He is the author of Democracy in Divided Societies: Electoral Engineering for Conflict Management (Cambridge University Press, 2001) and three other books on related subjects, and is currently working on a new book on democracy, ethnicity and governance in the Asia-Pacific region. An earlier version of this paper was presented to the Annual Conference of the Australasian Political Science Association in Hobart, 1-3 October 2003. 
tional transfer that have served to export the 'Australian' system to other countries-via a process of institutional transplanting generally associated with colonial rule and decolonisation; via exposure to international forces, often in the form of international experts recommending electoral systems models; and via domestic adoption based on the appeal of the preferential system itself. It finds little support for the contention that Australia has deliberately attempted to transplant its electoral institutions overseas. Rather, the normative appeal of preferential voting, not its connection with Australia, appears to be the predominant reason for the newfound interest in the system abroad.

\section{Background}

Australia has a long history of democratic innovation, particularly in terms of electoral procedures. Universal manhood suffrage, candidacy and voting for women, the use of ballot papers to record votes, the secret ballot, voting by mail, Hare-Clark proportional representation, and a range of innovations in electoral administration are just some of the areas in which Australia was an international pioneer in the 19th and early 20th Centuries (Sawer 2001).

Perhaps the most influential Australian contribution in this field, however, has been in the area of electoral system innovation. In particular, Australia's use of 'preferential' voting systems-that is, systems which enable electors to rank candidates in the order of their choice on the ballot-represents an important case of electoral system design and diffusion. All three of the world's major preferential electoral systems - the alternative vote, or AV (the most widely-used form of preference voting in Australia), the 'contingent' or 'supplementary' vote (now abandoned in Australia but increasingly used elsewhere), and the single transferable vote, STV (and its distinctive Australian variant, Hare-Clark)-were developed or substantially refined in Australia. In large part because of this, the Australian history of electoral innovation represents one of the more distinctive national contributions to institutional design (McLean 1996, 369).

The Australian influence on the diffusion of preferential voting systems elsewhere has been mixed. Despite its early adoption by Tasmania in 1907, the STV form of proportional representation invented by Thomas Hare and Carl Andrae in the 1850s was not adopted at the national level in Australia until 1949, post-dating its introduction in Malta (1921) and the Republic of Ireland (1922). Conversely, for much of the past century, the most common form of preferential voting in Australia, AV, attracted relatively little interest abroad. Until very recently, the only cases outside Australia to have used the alternative vote for parliamentary elections were the Canadian provinces of Alberta, British Columbia and Manitoba between 1926 and 1955, and two Pacific territories administered by Australia, Papua New Guinea and Nauru, during their process of decolonisation in the 1960s and 1970s. ${ }^{1}$

In recent years, however, preferential voting has become an increasingly popular electoral system choice in a number of new and established democracies. For example, in 1997, Fiji adopted AV, and has since held two elections (punctuated by a coup) under this system. In August 2001, the parliament of Papua New Guinea approved long-awaited electoral reforms which reintroduced

\footnotetext{
${ }^{1}$ In an unusual sideline, AV was also used as the electoral system for the twenty 'white' seats in Zimbabwe's 1980 and 1985 elections.
} 
a 'limited preferential' form of AV for future elections. Preferential systems have also been adopted recently in countries with no historical links to Australia or the wider Commonwealth. Estonia, for example, used STV for its first post-Soviet elections in 1990 before abandoning it, while in 2000 Bosnia also adopted AV for some sub-national elections. Similarly, AV has become a popular choice of electoral reformers in the United States. In 2002, San Francisco adopted AV for future city elections, and an unsuccessful initiative ballot to adopt the system for all State elections was held in Alaska. Other proposals to introduce preferential voting have also been put forward in a number of other US States and in Canada.

What explains this sudden upsurge of interest in what is generally considered to be a relatively unusual form of electoral system? Has Australia become an institutional imperialist, transferring its own political arrangements to others? Are Australian officials, as some have claimed (Rydon 2001), engaged in a deliberate process of transplanting their preferred electoral systems abroad? To answer these questions, this article examines the details and patterns inherent in the international diffusion of preferential voting. First, however, it is necessary to give a background typology of the various kinds of preferential systems.

\section{A Typology of Preferential Voting Systems}

Preferential electoral systems come in a variety of formats. AV is the most common form of preferential voting in Australia, being used for Federal elections to the House of Representatives and all State and Territory lower houses bar Tasmania and the Australian Capital Territory. Under this system, voters rank-order candidates on the ballot paper in order of their choice, by marking a ' 1 ' for their most favoured candidate, a ' 2 ' for their second choice, ' 3 ' for their third choice and so on. A candidate who gains an absolute majority of first-preferences votes-as happens in roughly half of all cases-is immediately elected. If no-one has a majority, the candidate with the lowest vote total is 'eliminated' and his or her ballots re-examined for their second preferences, which are assigned to the remaining candidates in the order as marked on the ballot. This process is repeated until one candidate has an absolute majority or until there are no votes left in the count.

A more obscure historical variant of preferential voting is the contingent vote (CV) used in Queensland between 1892 and 1942. This system resembles AV, in that any candidate who receives an absolute majority of first preferences is declared elected. If no candidate has an absolute majority, however, the elimination process changes: all candidates other than the two leaders on first preferences are eliminated, and the votes for eliminated candidates are re-distributed to one or the other of these top two, according to the preferences marked, to ensure a majority winner. While superficially similar to AV, this system can deliver quite different results, particularly under conditions of high candidature. While it is no longer used for elections in Australia, CV was used in some US State primary elections earlier this century, and (since 1978) for Presidential elections in Sri Lanka. In 1993, it was recommended as a new electoral system for Britain by the Labour Party's Plant Commission, who (thinking they had invented a new system) called it the 'supplementary vote'. Although not adopted at the national level, this was used for London's first-ever Mayoral elections in May 2000, which was won (on second 
preferences) by 'Red Ken' Livingstone. The system has thus been independently 'invented' on at least four separate occasions (see Reilly 1997a).

Finally, the STV form of proportional representation has attracted legions of admirers and many advocates in the political-science community, but has been introduced in relatively few countries. STV utilises multi-member districts, with voters ranking candidates in order of preference on the ballot paper in the same manner as the alternative vote. After all first-preference votes are tallied, the count begins by establishing the 'quota' of votes required for the election of a single candidate. Any candidate who has more first preferences than the quota is immediately elected. If no-one has achieved the quota, the candidate with the lowest number of first preferences is eliminated, and his or her second preferences redistributed to other candidates left in the race. At the same time, the surplus votes of elected candidates (ie those votes above the quota) are redistributed according to the preferences marked on the ballot paper until all seats for the constituency are filled. STV is used today for elections to the Australian Senate, to the lower house in Tasmania, to the unicameral Australian Capital Territory Legislative Assembly, and farther afield in Malta, the Republic of Ireland, and Northern Ireland.

Terminology is a problem in this field. What is typically called preferential voting in Australia is, in reality, one form of preference voting system, the alternative vote- a term also used in Fiji and the United Kingdom, and in most of the academic literature. In the United States, however, the alternative vote is popularly known as 'instant runoff voting' or IRV, having been re-labelled as such by proponents of electoral reform. In Papua New Guinea, it is now known as 'limited' preferential voting. In Britain, what was called the contingent vote in Australia is called the 'supplementary vote'. To further complicate matters, the term 'preferential voting' is also sometimes used by some scholars to refer to the kind of open-list voting in proportional systems common in continental Europe, most of which give voters some choice as to the ordering of candidates within a party list but without any facility for rank-ordering (see eg Katz 1986).

\section{Preferential Voting Internationally}

The three different kinds of institutional transfer noted earlier have resulted in distinctive patterns of diffusion of preferential voting internationally. In earlier decades, the colonial transplanting of the system from Australia to its overseas territories was clearly the most influential of these. However, in recent years this has changed. Over the course of the 1990s, the internationalisation of electoral assistance, coupled with the increasing normative appeal of preferential voting systems, has become a paramount factor determining institutional choice. This is in part because of the globalisation of electoral and democracy assistance that has taken place since the fall of the Berlin Wall, which has provided an important opportunity for the diffusion of what have been, for the most part, distinctively 'Australian' practices and procedures.

Colonial transplanting, the first form of diffusion of preferential voting, occurred primarily within Australia's regional 'sphere of influence', the South Pacific. In an article on policy transfer in the Pacific, Larmour (2002) argues that the transplanting of Westminster political institutions into the Pacific Islands region was essentially a process of replication, by which familiar metropolitan institutions were transferred to new states irrespective of underlying social and political conditions. 
During the 1960s and 1970s, successive Australian governments transplanted elements of their own political system, including Australia's electoral arrangements, to the two Pacific states with which it had some form of colonial relationship, Papua New Guinea and Nauru.

Neither transfer lasted for long. Papua New Guinea abandoned the alternative vote in favour of a plurality system at independence in 1975, while Nauru used it for one election only before modifying the system to invent a unique version of the Borda count (see Reilly 2002a). Australia's relatively brief engagement as a colonial administrator of Pacific island territories does not appear to have created the kind of deep attachment to Australian electoral practices that has sustained British, French and American political structures in post-colonial Africa, Asia and Latin America. By the 1980s, outside of its established foothold in Australia, there was relatively little knowledge of or interest in the alternative vote as an electoral system model that other countries may wish to emulate or adopt.

This changed with the fall of the Berlin Wall in 1989 and the subsequent collapse of authoritarian regimes around the globe. Working its way though Eastern Europe, Latin America, Africa, and Asia, the 'third wave' of democratisation resulted in a three-fold increase in the number of competitive democracies around the world (Huntington 1991). As new constitutions were drafted, new electoral arrangements debated, and new political systems introduced, the third wave resulted in a tremendous upsurge in interest in the possibilities of political engineering via electoral system choice and other designs for democracy.

Accompanying this was a change in the dynamics of international development aid and the role of multilateral institutions such as the United Nations. The international community began to invest heavily in the concept of democracy promotion, electoral support and 'good governance' as essential elements of economic development and the creation of stable and peaceful new states. The UN established an Electoral Assistance Division, while regional bodies like the Organisation of American States, the Organisation of African Unity (now the African Union), the Organisation for Security and Cooperation in Europe, and the European Union all established democracy promotion units (Santiso 1998).

Responding to the increased flow of development aid into this field, international democracy-promotion organisations like the International Foundation for Election Systems, the National Democratic Institute, and the National Endowment for Democracy (all US-based), the German Stiftungs, and the Stockholm-based International Institute for Democracy and Electoral Assistance (of which Australia was a founding member) all made electoral assistance a primary focus of their work program, as did resurgent multilateral bodies such as the Commonwealth Secretariat and the United Nations Development Program. Within a few short years, international democracy assistance became a major growth industry.

This process impacted upon the flow of ideas and experience around the globe. In 1990, for example, the small Baltic state of Estonia held its first post-Soviet elections under a combination of AV and STV - a system which had been popularised by Rein Taagepera, an expatriate Estonian political scientist from the University of California, Irvine, who was also a Presidential candidate in Estonia. While this system appeared to work fairly well, the Estonians decided to adopt a more mainstream form of party-list proportional representation for their future elections (Taagepera 1996). Nonetheless, the diffusion of preferential voting to Estonia - the first country without a British colonial heritage to use the system- 
was a pointer to the way in which new information flows about political institutions internationally were impacting on the choice of electoral systems.

Since then, different forms of preferential voting have been recommended for or adopted in a range of countries. In 1999 in Bosnia, following a lengthy inquiry into electoral reform options, the United Nation's High Representative recommended a package of electoral reforms which included the introduction of a preferential voting system for future Presidential elections. While this was not implemented, an AV system was adopted for Presidential elections in Bosnia's 'constituent entity' of Republika Srpska, being used for elections in November 2000 and again in 2002.

In the United Kingdom, interest in various forms of preferential voting has waxed and waned over the years, but was stimulated by the Plant Commission's proposal for the supplementary vote in 1993, which generated a considerable (and largely negative) response (see Plant Commission 1993). Following its election in 1997, the Blair Labour government pledged to hold a referendum on electoral reform during its first term of office, under pressure from its (then) LiberalDemocrat allies. This did not take place, and another inquiry into the electoral system was held instead. In 1998, the Jenkins Commission unveiled a proposal for 'AV plus' - a mixed system with $80 \%$ of seats elected by AV, and the remaining $20 \%$ elected from a PR list to balance proportionality-as its recommendation for a future electoral system for Britain (Jenkins Commission 1998). But this also appears to have lost support, and despite influential support for 'pure' AV from some quarters-including former Minister Peter Mandelson and the Economist magazine (Economist 28 October 1995) — there are strong systemic forces in favour of the status quo.

As noted earlier, AV has also been adopted by two South Pacific countries, Fiji and Papua New Guinea (PNG), in recent years-not as a result of transplanting from Australia, as in earlier decades, but following their own independent inquiries. In Fiji, a Constitution Review Commission (hereafter CRC) recommended in 1996 that an unusual form of multi-member AV be introduced for elections in Fiji in order to promote the development of 'multi-ethnic politics' in a society divided between indigenous Fijian and Indo-Fijian communities (CRC 1996). After a protracted debate, an unusual form of single-member AV was subsequently implemented for Fiji's 1999 elections-which were won in a landslide by the Fiji Labour Party, resulting in its leader, Mahendra Chaudhry, becoming Fiji's first ever Indo-Fijian Prime Minister. Following the armed overthrow of the Chaudhry government in May 2000, there were calls for a new electoral system. Nonetheless, a second AV election was held in 2001, resulting in the re-election of the military-appointed Fijian Prime Minister, Laisenia Qarase.

In Papua New Guinea, the Constitutional Development Commission recommended in 2000 that PNG re-adopt preferential voting, after two decades of elections had exposed the weaknesses of using a plurality system in a situation of great social heterogeneity. ${ }^{2}$ Legislation to effect this change was passed in early 2001 , along with a range of other reforms intended to encourage the development of a more cohesive party system, stabilise the formation of executive government and restrict the ability of members to change parties once elected. The new system

\footnotetext{
${ }^{2}$ One of the most marked weaknesses was the propensity of plurality elections to deliver winning candidates with extremely limited support levels. Most successful candidates elected at the 2002 elections, for example, gained less than $20 \%$ of the vote, and some were elected with as little as $5 \%$.
} 
is a version of AV known as 'limited preferential' voting in which electors have to mark a minimum of three preferences to effect a valid vote. It will be used at the next general election scheduled for 2007 (see Reilly 2002b).

In both Fiji and Papua New Guinea, the adoption of AV has not been without controversy. While the immediate pressure for further electoral reform in Fiji appears to have passed, it remains to be seen whether the complexities of AV will be feasible in PNG, not least in terms of the administration of elections. And, while the decision to adopt AV was taken by and for local actors in both PNG and Fiji, there is no doubt that the proximity of Australia carried some weight when assessing electoral options in each case. Indeed, the Fijian CRC specifically made reference to the usefulness of having a near neighbour with a long record of experience of preferential voting when they recommended it for their country (CRC 1996, 326). In this sense, the regional imitation thesis does have some value.

One country where this is assuredly not the case is the United States, which in some ways represents the 'last frontier' of electoral reform. As a country whose self-image is based around its claim to be the world's oldest and greatest democracy, comparative international experience has little value in marketing domestic political reforms. Despite this, there has been a sustained push to introduce preferential voting in a number of US jurisdictions in recent years. Various preferential voting systems were once relatively widespread in the US, being used for local elections in around two dozen cities over the course of the twentieth Century. But reform movements sponsored by their party machines led to replacement, in virtually all cases, by plurality systems (the main exception being local elections in Cambridge, Massachusetts, which continues to use STV). ${ }^{3}$

Recent years, however, have seen a burst of enthusiasm for the adoption of 'instant runoff voting' or IRV, the name popularised by US electoral reformers as a local moniker for AV. This has some historical precedent: AV was in fact invented by a Harvard professor, W.R. Ware, in 1871 as a modification to Thomas Hare's earlier proposals for STV (Reilly 2001, 34). Since the famously flawed 2000 elections, legislation to introduce preferential voting has been introduced in over 20 US States and in Congress. Major initiatives include the following:

- On 5 March 2002, San Francisco voters adopted instant runoff voting by a 55-45\% margin for all future city elections. The first application is due to take place in the November 2004 election for the office of Mayor, District Attorney and Sheriff and for all subsequent races for Supervisor, Treasurer, City Attorney, Public Defender and Assessor.

- On 27 August 2002, a Statewide plebiscite on the introduction of IRV was held in Alaska at the initiative of the local Republican Party (who were losing votes to a right wing challenger, the Libertarian Party). The initiative lost by a vote of 64-36\%. If successful, it would have been the first major electoral system reform

\footnotetext{
${ }^{3}$ One reason for the hostility of the major parties to preferential voting was the benefits it gave to minority candidates, particularly racial minorities. For example, in 1975 the contingent vote was re-introduced in Ann Arbor, Michigan, for Mayoral and Council elections. The presence at that time in Michigan of a third party, the Human Rights Party, created a genuine three-way contest which saw the first ever black Democrat Mayor elected on the strength of second preferences transferred from the eliminated Human Rights Party. This victory prompted Republicans, the beneficiaries of votesplitting under plurality rules, to lead a repeal effort, which was ultimately successful. See Amy (1993).
} 
in the United States for many years, as it would have applied to most elections conducted in the State, including Presidential elections.

- In 1999, the Vermont Commission to Study Preference Voting released an influential report, entitled As Easy as 1-2-3, which recommended that IRV be adopted for all State and Federal elections in Vermont (see Vermont Commission 1999). Legislation to adopt IRV has been introduced in every session of the Vermont legislature since 1998, accompanied by a grass-roots campaign from civic groups, labour unions and other progressive movements.

- Legislation to adopt IRV elections has also been introduced in a range of other US State legislatures including Arkansas, California, Connecticut, Florida, Hawaii, Illinois, Maine, Massachusetts, Minnesota, New Jersey, New York, Texas, Virginia and Washington, and in the Federal Congress. However, in most cases reform proposals have not progressed beyond this initial stage and have limited prospect of doing so in the foreseeable future. ${ }^{4}$

\section{Why?}

What is driving this recent and unexpected enthusiasm for preferential voting in so many different countries? The answer to this question depends primarily on the country in question, as local political factors are always central to electoral reforms and, of course, vary widely from place to place. In general, however, reform advocates typically cite one of five putative benefits of preferential voting: (1) the majority threshold for electoral victory inherent in AV elections; (2) the aggregation of common interests that vote transferability makes possible; (3) preferential voting's utility in negating the impacts of vote-splitting; (4) the extent of information that voters can express under preferential systems; and (5) the role that 'preference-swapping' can play in promoting centrist and accommodative political outcomes. The following discussion looks at each of these issues in turn.

\section{Majority victories}

Because preferential systems like the alternative vote (and, to a lesser extent, the supplementary vote) require winning candidates to gain an absolute majority of the vote for victory-either outright on first preferences or via the transfer of second and later preferences-they have a clear advantage over plurality systems like first-past-the-post. Winning candidates can thus claim a mandate to represent a genuine majority of the electorate, in contrast to plurality elections where winning candidates are often elected on a minority of the vote. This is an important issue for electoral reformers in both the UK (in which minority victories has long been an issue of concern) and in the USA (particularly after the last Presidential election, won by George W. Bush with about half a million fewer votes than Al Gore).

This problem of minority victories has been taken to an absurd extreme under plurality elections in Papua New Guinea, which has regularly seen winning candidates elected on $10 \%$ of the vote or less, and in which the 2002 parliament (the last to be elected under plurality rules) has, on vote totals, been rejected by

\footnotetext{
${ }^{4}$ For more information on all of these cases, see the website of the Center for Voting and Democracy, the major electoral reform lobby group in the United States (Center for Voting and Democracy 2004).
} 
over $80 \%$ of the population. It is this single fact more than any other that has driven the reintroduction of $\mathrm{AV}$ in PNG.

Despite this, preferential voting does not guarantee that the party that wins the most votes after the distribution of preferences will necessarily win government, and it is quite possible for a party to win an overall majority of votes but still 'lose' the election. This has happened at several recent Australian elections at both the State and Federal level. This weakness of preferential voting is, however, not widely understood.

\section{Aggregating Common Interests}

Elections held under preferential voting enable the votes of aligned candidates to accumulate so that diverse but related electoral interests can be aggregated. The long-standing coalition agreement between the Liberal and National Parties in Australia, which allows both parties to stand candidates in 'three-cornered contests' against Labor and direct preferences to each other, is probably the best example of this arrangement in practice. Indeed, it is unlikely that the Coalition agreement could have been maintained under a different electoral system.

Preference distribution in Australian politics has seldom facilitated the collaboration of both major parties against a common foe. The 1998 Federal election, however, provided an example of this via the reaction of the major parties to Pauline Hanson and the One Nation party. In their 'how-to-vote' cards for the seat of Blair, which Hanson was contesting as One Nation leader, both the Liberal and Labor parties advised their supporters to place Hanson last when marking their ballot (in contrast to the more familiar tactic of placing their major party opponent last). While Hanson led the first preference count with $36 \%$ of the vote, as a result of this decision she received very few preference transfers from other candidates, losing the seat when $73 \%$ of preferences from the eliminated Labor candidate went to a Liberal at the final count.

\section{Combating Vote-Splitting}

A third reason for the upsurge of enthusiasm in preferential voting in recent years in all countries, particularly the US, is the problem of 'vote-splitting'. Under plurality elections, a majority vote that is 'split' by the presence of a new challenger on the same side of politics is an endemic problem. The way Ralph Nader split perhaps $2 \%$ of the Democrat vote away from Al Gore at the last US Presidential election, effectively swaying the outcome in favour of George W. Bush, is a case in point. Under preferential voting, it is reasonable to assume that some of those votes split away would have come back to the Democrats in the form of second preferences. As it was, they were lost to Nader, and so Bush won the election even though he was clearly the less popular candidate overall (of course, the election result in his favour was ultimately determined by the US Supreme Court).

Vote-splitting is also a major issue in US States such as New Mexico and Alaska, where the emergence of viable third parties have splintered the core vote base of the major political parties. In New Mexico, where the Greens and Democrats have split the 'liberal' vote, giving Republicans minority victories, leaders in the Democratic Party are actively pursuing AV as a remedy. In Alaska, 
the Republicans-who have been outflanked by other right-wing parties-were the primary movers behind the failed 2002 vote to introduce preferential voting for future elections there.

Combating vote-splitting was also a major reason for the adoption of preferential voting in Australia. AV was introduced for national elections in 1918 following a by-election for the seat of Swan in Western Australia, which was won by a Labor candidate with $35 \%$ of the vote despite the three non-Labor candidates collectively mustering $65 \%$. When this result threatened to be repeated at another by-election in the Victorian electorate of Corangamite later that same year, the Hughes government (under pressure from the farming lobby, which threatened to split the Nationalist Party's vote by standing its own candidates) introduced AV for the House of Representatives in order to counter future vote-splitting, and to reward coalition arrangements between parties. In the Corangamite by-election the new system did exactly that, enabling the election on preferences of a Victorian Farmers' Union candidate over a Labor candidate who had led on first preferences (Graham 1962).

\section{The Power of Preferences}

Another purported advantage of a preferential ballot is that it elicits a more sophisticated range of information from voters about their opinions than most other electoral systems. Under preferential voting, electors are asked not just to chose their favourite candidate, but also who their second choice would be if their favoured candidate were to lose, who their third choice would be if neither of the first two won, and so on. The degree of information about voters' preferences elicited by the system is thus far higher than other systems, most of which only enable an elector to name his or her first choice.

Because of this, office-seeking parties and candidates contesting AV or STV elections have a strategic incentive to pursue the preference votes of minor party voters, while minor parties have an incentive to bargain with big parties for secondary support. In Australia, trading in preferences by parties-particularly between the House of Representatives and the Senate as part of 'cross-house' preference transfers-is now a standard feature of elections: some parties have 'developed the practice of cross-house preference deals to the point where negotiations become routinised' (Sharman et al 2002, 556).

Because the most successful parties in a political systems like Australia's will be those that command the middle ground in terms of the preferences of the median voter (thus assuring them of a healthy preference flow from minor parties), preference-swapping should, in theory, promote 'centrist' politics, as the big parties have an incentive to be as encompassing as possible (in order to pick up the second preferences of minor party voters) while the minor parties have an opportunity to influence the policies of the bigger parties (by directing their preferences towards a particular party). This model assumes, implicitly, that voters are arrayed along a Downsian bell curve, with a majority of moderates in the middle and extremists on either end. There is some evidence for this from Australian elections, where minor parties like the DLP in the 1960s, the Democrats in the early 1990s, and the Greens today, have had an important influence on election outcomes. 


\section{Moderate Politics}

In part because of these characteristics, some scholars have argued that preferential voting can encourage centrist forms of political competition, making it particularly appropriate for societies divided along ethnic or other lines (see Horowitz 1985, 1991). Building on Horowitz's work, I have argued elsewhere that the need to reach preference-swapping agreements under such systems can create 'arenas of bargaining' between rival candidates and parties, giving them room to explore potential areas of commonality not just on political strategy but on substantive policy areas as well (Reilly 2001). This is a well-institutionalised aspect of preferential voting in Australia, and has been an important positive benefit in other countries like Northern Ireland, where vote transfers clearly benefited pro-agreement forces at the breakthrough 1998 'Good Friday' STV elections. In fact, I think the cooperation-inducing elements of preferential voting are its single most important and distinctive attribute, although these are seldom, if ever, identified by mainstream analysts in Australia.

Elections held under AV rules in Papua New Guinea in the 1960s and early 1970s offer perhaps the best example of the way preference-swapping strategies can promote inter-ethnic moderation. This was, in part, because of the way AV changed the nature of election contests away from a zero-sum to a positive-sum game, to use the language of game theory. Under plurality or list PR electoral systems, more votes for you always means less votes for me. There is no escaping this basic rule. Under preferential voting, by contrast, more votes for you can still come back to me in the form of second preferences. In places like PNG, where the harsh logic of game theory actually works quite explicitly in practice, plurality elections are characterised by extremely high levels of electoral violence in some areas, in part because of this basic problem. This is in contrast to the experience of preferential voting elections in the 1960s and 1970s, which elicited much more cooperative strategies, often forged on the basis of traditional tribal alliances (Reilly 2001, 2002a).

However, other evidence for the accommodative impacts of AV is more mixed. In the only country which has deliberately introduced preferential voting to try to 'engineer' multi-ethnic politics, Fiji, the introduction of AV appears to have done little to stabilise national politics, given that the May 2000 coup occurred one year to the day after the first AV election. On the other hand, the two Fijian elections held under preferential voting rules in 1999 and 2001 both provide some evidence that preference swapping negotiations between parties may play a useful role in promoting cross-cultural communication, understanding and reciprocity (see Lal 1999; Reilly 2002c).

\section{Conclusion}

To answer the question posed in the title of this paper: is the worldwide spread of preferential voting the result of institutional transfer from Australia, international imitation, or normative appeal? The answer is mostly the latter, the normative appeal of the system, but for different reasons in different places.

One clear normative attraction of preferential voting systems such as AV has been their potential centripetal influence on elections in plural societies, such as Fiji or Papua New Guinea, and indeed farther afield in places like Bosnia or Northern 
Ireland. In PNG, for example, arguments in favour of the re-introduction of AV have centred on the need for majority victors and inter-tribal accommodation. In Fiji, similarly, the overwhelming rationale was to attempt to engineer multi-ethnic politics via cross-ethnic preference swapping. The adoption of preferential voting for sub-national elections in Bosnia, where international interest saw a great deal of focus on different models of electoral systems, is another example of the diffusion of international options and norms leading to the choice of preferential voting as a means of conflict management. The application of STV elections in Northern Ireland (where it has been used since 1973) has been justified on similar grounds (for information on all of these cases, see Reilly 2001).

In other countries, such as the United Kingdom, the impetus for preferential voting is coming from different sources. There, AV is being pushed by two different groups: those who want to see true majority victories and thus a more majoritarian electoral system introduced for British elections, and those like the Electoral Reform Society who see it as a Trojan Horse for implementation of their favoured form of proportional representation, STV. As the two sides have almost nothing in common, and the current Labour government has a waning enthusiasm for tinkering with the system that has delivered them electoral victory, the most likely outcome in Britain is the maintenance of the status quo.

Finally, in the United States, the push for AV is being driven by a range of disparate factors: the disadvantages of traditional runoff elections, the negative consequences of vote-splitting under plurality contests, and the potential for 'instant runoff voting' to mitigate some of the more excessive forms of negative campaigning. As vote-splitting in particular is an issue that afflicts major political parties in a number States and cities, there is a real prospect of more sub-national jurisdictions choosing to adopt AV in the future-particularly where runoff elections are currently used, meaning that such reforms can be sold on the basis of future cost savings. The biggest impediment to AV is not political, but administrative: the voting machines used in most US jurisdictions are not equipped to handle ranked ballots, and even the new electronic or touch screen technology appears to suffer from similar problems. Moreover, despite the burst of enthusiasm for electoral reform in the wake of the 2000 Presidential election, genuine prospects for electoral reform at the national level remain remote.

By contrast, there is little evidence that the recent enthusiasm for preferential voting abroad is the result of deliberate transplanting by Australia, although that has not stopped some commentators from claiming this is the case. In particular, recent articles by both Jon Fraenkel (2001) and Joan Rydon (2001) have alleged that Fiji was the victim of an inappropriate transfer of Australian institutions. Fraenkel, for example, argued that while the Fiji CRC's report 'bore evidence of considerable familiarity with contemporary scholarly literature on electoral systems', the actual application of AV in Fiji was a form of 'ballot-rigging' which was 'strongly influenced by the practice of preferential voting in neighbouring Australia, and reflected the input of the Australian Electoral Commission' (Fraenkel 2001, 8-9). Rydon's accusations went much further. Favourably citing Fraenkel, she claimed that nameless 'Australian electoral officials' who 'believe that they administer the perfect voting system' had 'attempted to export it' (Rydon 2001, 48).

None of these claims is correct. AV as it has been applied in Fiji has some real weaknesses, but most of these stem from the flawed model proposed by the CRC 
(and later amendments inserted by the Fijian parliament), rather than emanating from Australian practice. Even the main exception to this statement-Fiji's introduction of a 'ticket' vote system, as used for Australian Senate elections-was applied in a context quite unlike anything that has been tried in Australia. ${ }^{5}$ Moreover, far from demonstrating genuine expertise on electoral systems, the CRC's proposals clearly suffered from a lack of familiarity with the practicalities of electoral system design, as I have argued elsewhere (Reilly 1997b).

As to Rydon's unsubstantiated allegations of shadowy Australian electoral officials meddling in foreign countries, the truth is that the Fijians chose AV themselves, both as part of their own constitutional review and later through the Fijian parliament's acceptance of the CRC's recommendations and the drafting of new electoral laws, a process clearly set out in the commission's own report (CRC 1996) and subsequent accounts of the workings of the CRC and its aftermath (see, for example, Lal 2002). What external influence there was came chiefly from US-based academics, particularly the arguments of Donald Horowitz, a Duke University professor, in favour of AV.

Similarly in Papua New Guinea, another country within Australia's 'sphere of influence', the recent adoption of preferential voting was driven overwhelmingly by local concerns, not those of Australia. While several Australian commentators, myself included, have certainly advocated electoral reform in PNG, their influence on the actual adoption of preferential voting there has been, at best, marginal. As in Fiji, local considerations were paramount. The foremost proponent of reintroducing preferential voting in PNG was the late Sir Anthony Siaguru (2001), a former Cabinet Minister, and domestic politics, particularly the reform agenda of former Prime Minister Mekere Morauta, were the decisive forces behind the electoral reforms (see Reilly 2002b).

In sum, it is predominantly the normative appeal of preferential voting that is driving its adoption around the world, rather than the fact that it is used in Australia. This may disappoint any would-be imperialists eager to transfer local institutions to distant climes, and indeed any academic conspiracy theorists suggesting the same. They can be mollified, however, in the knowledge that an institution substantially developed and refined in Australia is attracting such widespread interest as a potential electoral system choice.

\section{References}

Amy, D. 1993. Real Choices/New Voices: The Case for Proportional Representation Elections in the United States. New York: Columbia University Press.

Center for Voting and Democracy. 2004. Website. Takoma Park MD. < http://www.fairvote.org > .

\footnotetext{
${ }^{5}$ A 'ticket vote' enables voters to forego the task of manually ranking all candidates on the ballot by instead opting to accept their favoured party's full preference distribution, from a list lodged with the electoral authorities. It has never been applied to AV elections in Australia, and created major problems in Fiji, where approximately 95\% of voters in 1999 chose the ticket vote option. Because electors were encouraged to accept a party's pre-set preference ordering, this had the effect of pushing decisions on preference marking out of the hands of voters and towards party elites. Because it was ultimately party leaders, not voters, who determined where preferences would be directed, ticket voting served to undermine the incentives for preference-swapping between candidates, as deals struck in advance at a national level formed the basis of most vote transfer arrangements. See Reilly (2002c).
} 
CRC [Constitution Review Commission]. 1996. The Fiji Islands: Towards a United Future. Parliamentary Paper No. 34 of 1996. Suva: Parliament of Fiji.

Fraenkel, J. 2001. 'The Alternative Vote System in Fiji: Electoral Engineering or Ballot-Rigging?' Commonwealth and Comparative Politics 39(1): 1-31.

Graham, B.D. 1962. 'The Choice of Voting Methods in Federal Politics, 1902-1918.' Australian Journal of Politics and History 8: 164-81.

Horowitz, D. 1985. Ethnic Groups in Conflict. Berkeley, CA: University of California Press.

Horowitz, D. 1991. A Democratic South Africa? Constitutional Engineering in a Divided Society. Berkeley, CA: University of California Press.

Huntington, S. 1991. The Third Wave: Democratization in the Late Twentieth Century. Norman, OK: University of Oklahoma Press.

Jenkins Commission 1998. The Report of the Independent Commission on the Voting System. London: Stationery Office.

Katz, R. 1986. 'Intraparty Preference Voting.' In Electoral Laws and their Political Consequences, eds B. Grofman and A. Lijphart. New York: Agathon Press.

Lal, B. 1999. A Time to Change: The Fiji General Elections of 1999. Canberra: Department of Political and Social Change, Australian National University.

Lal, B. 2002. 'Making History. Becoming History: Reflections on the Alleged Failure of the Fiji Constitution.' The Contemporary Pacific 14: 148-67.

Larmour, P. 2002. 'Westminster Constitutions in the South Pacific: A Policy Transfer Approach.' Asian Journal of Political Science 10: 41-54.

McLean, I. 1996. 'E.J. Nanson, Social Choice and Electoral Reform.' Australian Journal of Political Science 31: 369-85.

Plant Commission 1993. Report of the Working Party on Electoral Systems. London: Labour Party.

Reilly, B. 1997a. 'The Plant Report and the Supplementary Vote: Not So Unique After All.' Representation 34: 95-102.

Reilly, B. 1997b. 'Constitutional Engineering and the Alternative Vote in Fiji: An Assessment.' In Electoral Systems in Divided Societies: the Fiji Constitution Review, eds B. Lal and P. Larmour. Canberra: National Centre for Development Studies, Australian National University.

Reilly, B. 2001. Democracy in Divided Societies: Electoral Engineering for Conflict Management. Cambridge: Cambridge University Press.

Reilly, B. 2002a. 'Social Choice in the South Seas: Electoral Innovation and the Borda Count in the Pacific Island Countries.' International Political Science Review 23: 355-72.

Reilly, B. 2002b. 'Political Engineering and Party Politics in Papua New Guinea.' Party Politics 8: 701-18.

Reilly, B. 2002c. 'Electoral Systems for Divided Societies.' Journal of Democracy 13(2): 156-70.

Rydon, J. 2001. 'Fiji and the Export of Electoral Systems.' Australasian Parliamentary Review 16(1): $45-9$.

Santiso, C. 1998. 'International Dimensions.' In Democracy and Deep-Rooted Conflict: Options for Negotiators, eds P. Harris and B. Reilly. Stockholm: International Institute for Democracy and Electoral Assistance.

Sawer, M. ed. 2001. Elections: Full, Free and Fair. Sydney: Federation Press.

Sharman, C., A.M. Sayers and N. Miragliotta. 2002. 'Trading party preferences: the Australian experience of preferential voting.' Electoral Studies 21: 543-60.

Siaguru, A. 2001. In-House in Papua New Guinea with Anthony Siaguru. Canberra: Asia Pacific Press, Australian National University.

Taagepera, R.. 1996. 'STV in Transitional Estonia.' Representation 34: 29-36.

Vermont Commission. 1999. As Easy as 1-2-3: Final Report of the Vermont Commission to Study Instant Runoff Voting. Paper presented to Vermont House of Representatives pursuant to H.R. 37. January. 